\title{
Case Study: The Optimization of the Functions of Islamic Religious Education in Ponorogo
}

\author{
Ju'subaidi, Winantu Kurnianingtyas Sri Agung \\ Fakultas Tarbiyah dan Ilmu pendidikan \\ Institut Agama Islam Negeri (IAIN) \\ Ponorogo, Indonesia \\ jusubaidi@stainponorogo.ac.id,winantu.kurnianingtyas@gmail.com
}

\begin{abstract}
This article discusses the evaluation of supervision program as the main duties of Islamic Religious Education Supervisor at School. These duties include academic and managerial supervision conducted by Islamic religious education supervisors throughout Ponorogo schools. In this case, Ponorogo was chosen because the National award was given towards supervisors in Ponorogo Ministry of Religious Affairs. On the other hand, the author also finds many things that come along with that implementation. This research is an evaluation research with the qualitative approach. Data were revealed by interview and documentation and then analyzed by interactive analysis including data reduction, data display, and conclusion. The results of this study are academic and managerial supervision cannot be done maximally constrained technical and nontechnical. The non-technical constraints ideological differences between supervisors and teachers of Islamic Education, while technical constraints the different Ministries. Consequently, they must follow two standard rules.
\end{abstract}

Keywords-academicals and management supervisions; double standards

\section{INTRODUCTION}

Lately, the quality development of religion and religious education in particular, occupy a strategic and important role for Indonesian considering to high educational quality. Religious education becomes a determinant quality of Indonesian nation in the future [1]. This is affected by negative impacts of social culture and information globalization that led the nationality broken in Indonesia. In the last decades, morality in this nation is apprehensive. The high numbers of corruption, pornography, porno actions, promiscuity of increasing drug abuse, the decline of the authority of law, intolerance attitude and the various immoral behaviors are social that difficult to dam and overcome. Therefore, the efforts to develop and improve the quality of religion and religious education particularly become important to prevent, reduce and improve in society. However, someone who has good achievements in science without balancing moral quality and planting adequate religious values will undermine social life.

On the other hand, an educational quality that gained by every child has not been directly proportional to the high level of educational participation in Indonesia whether in basic and intermediate level. Providing good educational quality becomes the key to creating the quality generation. In line with UNESCO's statement on the launch of Global Education Monitoring (GEM) that reported on 2016, stated that the level of community participation in education has not been balanced with the educational quality that community gains [2] Educational quality should be commensurate with the level of community response toward education. Indonesian government's duties are harder because it ensures all children receive the same quality of education at school. UUD 1945 has mandated the Indonesia government to provide education for all children to be realized.

Institutionally, the implementation of religion and religious education has shown some progress, but it has some weaknesses in several aspects. Normatively, religious education has not played its role optimally as a formation of the expected community personality. On an economic point of view, religion and religious education outcomes are suspected not able to provide the provision of life (life capital). In this context, religion and religious education institutions are required to provide life skill to students based on religious values [3]. While in managerial level, religion and religious education cannot be managed professionally yet such as management principles and systemic control. As the bearer of the mandate, the government has an obligation to realize that expectations through institutions or related institutions.

The education officer and the Ministry of Religious Affairs as the agency that has a responsibility toward that demands should improve educational quality services, especially religious education. PERMENAG no. 2 of 2012 about Madrasah supervisors and PAI supervisors in schools is declared to show the government's efforts in realizing these demands are assisted by the existence of education supervisors.

School supervisors are well known in the community environment and in the world of education. The declarations of Menpan no 118 of 1996 about the functional positions of supervisors and credit numbers, Mendikbud regulation no. 03420/O/1996 and Kepala Badan Administrasi Kepegawaian Negara No 38 of 1996 about the guidance of the functional supervisors, and Mendikbud no. 020/U/1998 about the technical guidance of school functional supervisors and credit numbers, those have an important duty in improving the educational quality. However, the existence of school supervisors becomes separated discussion in the 
implementation education process of implementation of from primary to secondary level both supervisors in public education and religious education. Public education supervisors are as well-known as school supervisors who are systematically under Education and Culture Department at Regency level. While Religious education supervisors are under the coordination of Ministry of Religious Affairs of.

School supervisor is a government teacher who is appointed to school supervisory position. Mendikbud regulation no 020/U/1998 about technical guidance on school functional supervisors and credit numbers, PAN \& RB regulation no. 21 of 2010, article 4 said that school supervisor is a career official who can be occupied by government teachers. Moreover, a supervisor is a strategic position in education implementation. Thus, a supervisor is domiciled as a functional technical executive in the field of supervision that includes academic and managerial fields in establishing the educational unit. Hence, a supervisor is an accomplice of Education Department or Ministry of Religious Affairs in Regency.

Government regulation no 74 of 2008 about Teacher in article 54 paragraphs (8) and point d stated that teachers were appointed in the position of supervisor in Education Unit performs the duties of teacher guidance and professional training and supervision duties. Supervisory duties are referred to conduct supervisory activities both academic and managerial oversight [4]. The main duty of supervisor is to carry out academic and managerial oversight of education unit that covers supervisory formulation program, implementation of guidance, monitoring the implementation of Eight National Standards of education, assessment, guidance and professional training of teachers, evaluation of the goal of supervisory program, and implementation of regional supervisory duties in special areas. Those supervisory positions are important in education implementation and they should have the dominant contribution in its implementation of in Regency or city. The question is how much the main duty of the supervisors that can be played.

The existence of religious education supervisors in schools is a functionally important in involving religious educational quality. Meanwhile, at the implementation level, supervisors of Religious Education at schools carry out their main duty and their functions in facing significant constraints. On the other hand, institutionally, PAI supervisor is under Ministry of Religious Affairs while functionally located in Ministry of Education and Culture.

Structurally, Religious Education supervisors are under Ministry of Religious separated into madrasah supervisors and religious education supervisors as stated in PERMENAG Regulation no.2 of 2012. Meanwhile, Islamic education supervisors are called PAI supervisor at school is government teacher who appointed in the functional position of Islamic religious education supervisor whose has duties, responsibilities, and authority to supervise the implementation of Islamic religious education in schools rather than in madrasah. The difference between madrasah supervisor and Islamic religious education supervisor at the school lies in place of duty where supervisor performs his duties and functions.
As contained in PERMENAG number 2 of 2012 in article 3 , paragraph 2, PAI supervisor at school has a duty in carrying out supervision of Islamic religious education at school. Meanwhile, the PAI supervision function at school is to arrange the PAI supervision program, coaching, mentoring, and professional development of PAI teachers, monitoring the implementation of PAI national standards, conducting the monitoring program outcomes, and reporting the implementation of supervisory duties.

Taking into the duties and functions of supervisors on the level of implementation, supervisors face many technical and non-technical issues. Technical issues are such as technical counseling that takes place in a group of subject teachers and it is not often implemented by teachers in learning process, while non-technical issues such honesty, hard work, work discipline, time discipline, responsibility, low school community response, less synergistic cooperation between supervisors and schools and so forth are additional issue in implementing supervisory duties and its functions.

Therefore, this article tries to explain how the supervisors of Islamic religious education in schools are trying to carry out their main duty to improve the quality of Islamic religious education in schools. The discussion is based on the data that obtained in the field where the authorities deal with problems and overcome them.

\section{THEORY}

\section{A. Supervisor of Islamic Religious Education}

Optimization is the process of maximum improvement [5]. Optimization is the process of finding the best solution to some problems where "the best" accord to pre-stated criteria. The action of making the best or most effective use of a situation or resource [6]. In other words, optimization is an improvement process to find the best solution in some issues in accordance with certain criteria. In this article, the appointment is the optimization of academic and managerial supervision as the main duties of Islamic Religious Education (PAI) Supervisor in schools to increase the achievement of Islamic religious education objectives.

The school supervisor is a civil servant teacher who is appointed to the school supervisory position. The school supervisor is a career title in charge of direct or indirect observation of education providers [7]. The School Supervisor is located as a functional technical executive in the field of supervision that includes supervision of academic and managerial areas in the education unit. This education supervisor is divided into two namely the supervisor of madrasah and the supervisor of Islamic religious education. Madrasah supervisor is a civil servant teacher who is appointed in the functional position of supervisor of education unit whose task, responsibility and authority perform academic and managerial supervision on Madrasah covering kindergarten level, madrasah ibtidaiyah, Madrasah Tsanawiyah, and madrasah Aliyah. The Supervisor of Islamic Religious Education or called Supervisor of PAI at school is a civil servant teacher who is appointed in the functional position of Islamic religious education supervisor whose duty, 
responsibility, and authority to supervise the implementation of Islamic Religious Education At School. The working area of PAI supervisors in public schools is not a religious school. This article is directed to PAI supervisors at non-madrasah schools [8]. The function of PAI Supervisors in Schools includes; Preparation of program supervision, coaching, guidance, and professional development of teachers, monitoring the implementation of national education standards, assessment of the results of the implementation of supervision programs, and reporting the implementation of supervision.

The workload of Islamic religious education supervisors is set at 37.5 hours per week. Whereas in carrying out the duties of a supervisor of at least 20 teachers of kindergartens, elementary school, junior high school, and high school. Determination of the educational unit supervised by the supervisor shall be determined by the Head of Religious Affairs of the Regency / City by the approval of the Supervisory Group (POKJAWAS) at the Regency / City level. In the case of appointment of supervisory positions conducted by the Minister of Religious Affairs or acting appointed by the Minister in accordance with the provisions of laws and Regents / Mayors with the approval of the Provincial Ministry of Religious Affairs [8].

\section{B. Academic and Managerial Supervision}

The main duties of the supervisor of Islamic religious education as stated in PERMENAG No. 2 of 2012 carry out the supervision of Islamic Religious Education in School. Meanwhile, the implementation of supervision includes academic supervision and managerial oversight. Implementation of academic and managerial supervisory activities conducted by Islamic Religious education supervisors as stated in the Supervisory Guidelines of Primary and Secondary Schools includes guidance, monitoring, assessment, guidance and professional training on teacher competence and teacher basic tasks. Managerial supervision is a supervisory activity including coaching, monitoring, professional assessment of principals and education personnel on aspects of school management and administration to achieve learning objectives effectively and efficiently.

The aim of guidance in academic supervision is to improve teacher competence. The indicator of the success of the guidance is the improvement of teacher performance [9]. While coaching in managerial oversight of his suggestion is the principal in professional assistance and aims to improve the performance of principals and educational personnel.

Monitoring is an academic supervision activity aimed at obtaining information on implementation and achievement of Graduation Standard, Content Standards, and assessment standards in planning and implementation of the learning process. Monitoring in managerial supervision is to know the implementation and conformity of National Education Standards in the process of organizing education. Assessment in academic supervision is an assessment activity on teacher performance. On the other side, the assessment in managerial oversight emphasizes the assessments of principals in the education management.
The guidance and training contained in academic supervision lead to the improvement of teachers' ability to carry out the main tasks of teachers with the aim of improving teacher competence in learning and meeting teacher career development demands. The guidance and training in managerial competency is directed to lead the efforts to demand the knowledge and skills of headmaster and education personnel in the management of education units and the obedience of National Education Standards [10].

\section{METHODOLOGY}

This article was an evaluative research with a qualitative approach. Evaluative research is a study to measure the effectiveness of implementation [11]. Guba and Lincoln (1985) in Mertens stated that evaluation is a process that describes something that evaluated and assessed the advantages of things [12]. Furthermore, Mertens interpreted evaluation as an exercise that assesses the progress and the goal systematically and objectively. In addition, Hardly and Mitchell stated that evaluation is an assessment to create or support one or more service programs. In contrast, Patton said that the evaluation was used to reduce uncertainty decisions. The statements above illustrated that evaluation is a systematic action of a research procedure to measure the design, implementation, conceptualization, and usefulness of a program. This means that uncertainty over decisions can be minimized. This study was conducted on the supervisors of Islamic religious education because those have different work coaching areas. The juridical PAI supervisor is appointed by the ministry of education and culture while its guidance is under the Ministry of Religious Affairs and or KASI PAIS. Therefore, a PAI supervisor must follow the standards of the Ministry of Education and Culture and they also follow the standards of the Ministry of Religious Affairs. This will lead various problems in performing the main duty of supervision.

In this case, the researchers directed the objectives of this study to the Supervisors of Islamic education and the head of Islamic education which is structurally under the Ministry of Religious Affairs of Ponorogo. The Ministry of Religious Ponorogo was chosen since its ministry won first place in the Ministry of Religious Affairs ministry in 2014. The research proposal has also been presented at the seminar of State Institute of Islamic Studies of Ponorogo in April 2017 and declared eligible as a research proposal. Data collection was conducted for 6 months from May to November 2017. This research was conducted in 4 stages; problem identification, data collection, data validation, and directed discussion. Data were collected through unstructured interviews and observed with research subjects that suitable for the research problems. The researcher interviewed two groups, namely Kasi PAIS and PAIS supervisor. Those were interviewed separately, while the observations were conducted six times with the same instructions.

Furthermore, the researchers re-checked the collected data to the research subjects to ascertain the validity of the data. The final part of this research is to conduct triangulation through discussions with colleagues at IAIN Ponorogo and conducted a presentation to obtain inputs at international seminars at UIN Bandung Indonesia. 


\section{RESULTS AND DISCUSSION}

The data were collected for 5 months and this research got some findings that needed to be shared because it was considered important in the management of supervision to be followed up by the authorized authority. The main tasks of Islamic religious education supervisors in schools consist of academic supervision and managerial supervision, both of which have different working areas.

\section{A. Academic Supervision}

Madrasah or school is an institution change social condition. The process of working is always faced with an uncertainty and interdependence. The curriculum implementation is strongly influenced by the characteristics of schools and affects the characteristics of teacher behavior in a learning process. Then it indicated whether learning outcomes succeed or not. The curriculum can be realized if the implementation is controlled properly and continuously including supervision of the learning implementation.

Control and learning quality assurance are the supervision of learning process as mandated by government in process standard. The process of learning monitoring should follow these stages monitoring, supervision, assessment, and followup. Monitoring has been conducted during teacher planning, procurement, and assessment. The purpose of monitoring is to know the implementation of education with a predetermined plan. On the other hand, monitoring was expected to find various barriers in the implementation of educational programs. Through these monitoring activities, supervisors have found some problems to be gained from teachers of Islamic religious education. The problems were the abilities of Islamic education teachers in understanding the various regulations that are substituted the old regulations. So that, they must understand the new regulations while the old one was in early implementation. This is caused by the socialization of the regulation lately from the central to the regions that must be through Regional Official. On the other hand, regulatory arrangements obtained from Regional Offices by Head of PAIS Section and supervisors at the District level often lack enlightenment resulting in different understandings. This condition is inappropriate with Glickman [13]. He argued that in carrying out academic supervision effectively required conceptual, interpersonal and technical skills. The regulation understanding would be a necessity for headmaster and supervisor before mastering the technical supervision to enrich supervision optimally. The monitoring results of PAI supervisors, in general, have not fulfilled the targets. This is due to the limited facilities by the supervisors.

In general, the results of assessment activities as a series of academic supervision is quite good but some problems cannot be found the efforts. The problem is the number of educational units is not balanced with the number of PAI supervisors. There are 3 people as PAI supervisors that categorized into three types of supervisors, namely elementary school supervisors, junior high school supervisors, and senior high school supervisors as well as vocational schools. The comparison of the number of supervisors and teachers has not met the established standards. In elementary school, a supervisor should lead 604 teachers of Islamic education; a
Junior High School supervisor will nurture 60 teachers, and a Senior High School / MA / SMK has to lead 40 teachers. The ratio between supervisor and teacher is not balanced. While the standard regulation of the minister of Religion mentioned that a supervisor has to lead at least 20 teachers. It is too hard because he does not only supervise the academic but also managerial side. An excessive burden was impossible can be done by a supervisor so that the implementation of supervisory duties was not optimal.

Guidance and training activities were a series of academic supervision activities PAIS supervisory duties. Those activities were conducted for teachers of Islamic Religious Education in their respective schools. This guidance and training activity was a supervisory activity in improving teachers' ability of in carrying out their main duties of. The purpose of these activities was to increase teachers' competence in demanding career development through sustainable professional development. The various training activities have been conducted through seminars, strengthening workshops on professional competencies that are adapted to the regulations of the 2017 curriculum. Those activities will not be effective because the ratio of supervisors to teachers was not balanced. The workshop has become effective if the participants consist of 30 people. While the number of PAI teachers elementary school are 604. It is a very large number and takes several meetings to conduct training activities.

\section{B. Managerial Supervision}

Managerial oversight is school supervisors' duties that include guidance, monitoring, assessment, leading and professional training toward headmaster and education personnel on the aspects of school management and administration that are directly related to improving the efficiency and effectiveness of schools in supporting the learning process. Assessment of headmaster performance that was conducted by a supervisor is quite good, although not optimal yet. National education standards were used as the measurement. On the other side, program development, implementation, and evaluation are part of an endless effort to improve the quality of education and compliance standards should be continued. While the assessment of education personnel directed to administrative personnel. The ratio of administrative personnel to the number of schools was not balanced. The qualifications of administrative personnel mostly have been standardized. Most of the education personnel in private schools have not conducted quality assurance activities. Librarians have largely lacked librarian educational background and management and administrative do not relevant to library standards. Laboratory assistant of schools has not established the standards.

Conceptual guidance is part of managerial oversight that is the duties of school supervisors. The guidance is in the form of supervisory activities that conducted by school supervisors through professional assistance toward headmaster and educational staffs in order to increase their competencies and the evidence can be shown through the increasing teachers' performances. The results of managerial supervision by the school supervisor were shown good category. It indicates that the duties of managerial oversight have worked well. In order 
to achieve maximum standards would be required developmental performances continuously.

Monitoring conducted by supervisors was directed towards the implementation of eight standards that cover Standards of Content, Process Standards, Graduate competency standards, Education and education personnel standards, equipment and infrastructure standards, management standards, financial standards, and assessment standards. The observations of Islamic religious education supervisors include inappropriate facilities and monitoring activities do not fill the targets. As the consequence, the data cannot describe the actual conditions. Inaccurate information generates incorrect decision-making. Thus, it becomes inevitable to fulfill the targets of monitoring process as well as facilities fulfillment. The main factor in making the right decision is the proactive personnel in providing information to the supervisors will support in getting valid data. On the other hand, the selection approaches and monitoring strategies also affect the accurate information.

Follow-up activities refer to education policy that covering three pillars of national education policy, namely; assessing and expanding educational access, improving the quality, relevancy, competitiveness of education outcomes, and strengthening governance, accountability, and public coverage of education. The pillars of equity and the expansion of educational access includes the funding of 12 years operational expenses, the availability of educational facilities and infrastructure, educators and education personnel recruitments, the equitable distribution of information and communication technology, and the increasing participation of the community in the expansion of school access. While the pillars of improving quality, relevance, competitiveness of educational outcomes including efforts in increasing the number and quality of educators and educational staff and their inadequate welfare in quality and quantity, complementing learning facilities and infrastructure, improving its utilization optimally, and improving learning process that has not been effective and efficient. Furthermore, the pillar of strengthening governance, accountability, and educational public discourse that includes improving the system and organizational structure and governance, making systematic information systematic available by developing information and communication technology, and improving supervision system on various programs and activities related to equity and access expansion improvement and equity of education.

The regulation of the Minister of Religion about the total number of teachers for each supervisor was 20 people. Hence, the supervisors are able to perform their duties optimally. The inconsistency of Permenag number 2 of 2012 operationally raises several problems for supervisors at Ponorogo in particular. The problem is PAI supervisor has 2 main duties such fostering teachers of Islamic religion in school both at the primary and secondary levels within the Ministry of education and Culture, while supervision of PAI supervisors was held by Pokja Madrasah. In fact, PAI teachers structurally are under Islamic Religious Education Section (PAIS). On the other hand, the duplicate of the supervisors' duties demands the supervisor have to follow 2 rules as well as the rules applicable within the Ministry of Education and Culture and the Ministry of Religious Affairs. On the duties of managerial supervision,
PAI teacher faces its problems related to managerial oversight. The aspects of managerial oversight have become school supervisors that caused PAI supervisors do not supervise their schools. The problem required the authority of the Ministry of Religious Affairs of East Java Province transferring the duties of managerial supervision toward Madrasah Diniyah which is under the coordination of Islamic Boarding School (PONTREN).

The authority policy in upholding the supervisors of Islamic Religious Education without a recommendation from the regions is a psychological burden for the supervisors' selves. In fact, PAI supervisors structurally located in certain ministries while the coordination areas among PAI supervisors taken place in other Ministries. That condition made supervisor uncomfortable in coordinating among others. The impact of that policy affected in 12 supervisors of Islamic Education (Pendis) in the Ministry of Education and Culture replaced their position to Madrasah supervisors. Exchanging supervisor position was in order to clarify their positions that were under two different institutions. PENDIS supervisors are the ministry of Religion but their duties were under the Ministry of education and culture. Whereas supervisor of Islamic education is lacking positive responses in their school areas and even their duties do not often get recognition from the authority of the Education Official. Furthermore, the effect of that double treatment is the absorption of Teachers Professional Allowance (TPG) for several months and inhibition of supervisory careers.

Another arisen problem that was influenced by a favorable policy is the mapping of teacher competence within the Ministry of Religious Affairs cannot be completed. Sustainable Professional Education for teachers in the Ministry of Religious Affairs as additional issues that have not been a priority for implementation. The various issues above shown that Ministry of Religious Affairs policy was giving responses lately to the Government Regulation about education. As the result, they cannot arrange its regulation and its socialization soon. Therefore, the Ministry of Religious Affairs should release the Regulatory Ministry to District Office immediately. In hence, its policy was forwarded to Regency / City and socialized to various ministries that have relevance to that regulation.

\section{CONCLUSION}

The implementation of the main duty of Islamic Religious Education supervisors in the Ministry of Religious Affairs Ponorogo is not optimal because of the position of Islamic religious education supervisor in 2 ministry environment namely Ministry of Religious Affairs and Ministry of Education and Culture, unwell-coordination between the Ministry of Religious Affairs and the Ministry of Education and Culture on the regulation aspects of supervisors and education, unwell-socialization of Minister of Religious Affairs No. 2 of 2017 on madrasah supervisor and the supervisor of Islamic religious education, the weakness responses between supervisors and teachers as the result of ideological differences. 


\section{REFERENCES}

[1] N.K. Ridwan, Jurnal pendidikan Islam, Pancasila dan Radikalisasi berbasis agama, Vol. II, No. 1, 2013, p.148.

[2] Q. Tang, UNESCO, Global Educational Monitoring (GEM) Report, 2016. https://www.cnnindonesia.com/nasional/20160906155806-20156462/unesco-soroti-kesenjangan-kualitas-pendidikan-di-indonesia. Download, Januari 13, 2018.

[3] M. Arif, Jurnal Pendidikan Islam; Pendidikan agama Islam Inklusifmultikultural, Vol.1, No.1, 2012, p.11.

[4] S. Supraptanata, Panduan kerja pengawas sekolah pendidikan dasar dan menengah; Ditjen. Guru dan tenaga kependidikan, Direktorat Pembinaan Tenaga kependidikan Dasar dan menengah, Depdikbud. 2017, p.1.

[5] Kamus Besar Bahasa Indonesia, Jakarta, Balai pustaka, 1994, p.800.

[6] https://en.oxforddictionaries.com/definition/us/optimization, download November 1, 2017.
[7] Peraturan Pemerintah No. 74 Tahun 2008. Tentang Pengawas dan Peraturan Menteri PAN dan RB No. 21 Tahun 2010. Pasal 4.

[8] Peraturan Menteri Agama No. 2 Tahun 2012 Tentang Pengawas Madrasa dan Pengawas Pendidikan Agama Islam pada sekolah.

[9] Dirjen Pendidikan Islam Kemenag Ri, Pedoman Pembinaan Pengawasa Madrasah dan Pengawas PAI pada sekolah, 2017.

[10] Supraptanata, S. Panduan kerja pengawas sekolah pendidikan dasar dan menengah; Ditjen. Guru dan tenaga kependidikan, Direktorat Pembinaan Tenaga kependidikan Dasar dan menengah, Jakarta, Depdikbud, 2017, pp. 8-20.

[11] Joint Committee on Standards for Education Evaluation, Standards for evaluations of Educational programs, projects, and material, New York, Mcgraw-Hill Book Company, 1981.

[12] Donna M, Merters, Research and evaluation in education and psychology, California, Sage publication, 2010, p. 47.

[13] C.D. Glikman, Stephen. P, Gordon, Jovita M, Ross Gordon, Supervision and instructional leadership Canada PERSON, 2006. 